Article

\title{
Stress-Induced Gene Expression Sensing Intracellular Heating Triggered by Magnetic Hyperthermia
}

M. Elisa de Sousa, Alejandra Carrea, Pedro Mendoza Zélis, Diego Muraca, Olga Mykhaylyk, Yolanda E Sosa, Rodolfo G Goya, Francisco H. Sanchez, Ricardo A Dewey, and Marcela B. Fernández van Raap

J. Phys. Chem. C, Just Accepted Manuscript • DOI: 10.1021/acs.jpcc.5b12330 • Publication Date (Web): 10 Mar 2016

Downloaded from http://pubs.acs.org on March 10, 2016

\section{Just Accepted}

"Just Accepted" manuscripts have been peer-reviewed and accepted for publication. They are posted online prior to technical editing, formatting for publication and author proofing. The American Chemical Society provides "Just Accepted" as a free service to the research community to expedite the dissemination of scientific material as soon as possible after acceptance. "Just Accepted" manuscripts appear in full in PDF format accompanied by an HTML abstract. "Just Accepted" manuscripts have been fully peer reviewed, but should not be considered the official version of record. They are accessible to all readers and citable by the Digital Object Identifier (DOI®). "Just Accepted" is an optional service offered to authors. Therefore, the "Just Accepted" Web site may not include all articles that will be published in the journal. After a manuscript is technically edited and formatted, it will be removed from the "Just Accepted" Web site and published as an ASAP article. Note that technical editing may introduce minor changes to the manuscript text and/or graphics which could affect content, and all legal disclaimers and ethical guidelines that apply to the journal pertain. ACS cannot be held responsible for errors or consequences arising from the use of information contained in these "Just Accepted" manuscripts. 


\title{
Stress-induced Gene Expression Sensing
}

\section{Intracellular Heating Triggered by Magnetic}

\section{Hyperthermia}

\author{
M. Elisa de Sousa ${ }^{a_{\dagger}}$, Alejandra Carrea ${ }^{b_{\dagger \dagger}}$, Pedro Mendoza Zélis ${ }^{a}$, Diego Muraca ${ }^{c}$, Olga \\ Mykhaylyk $^{\text {d }}$, Yolanda E. Sosa ${ }^{\mathrm{e}}$, Rodolfo G. Goya ${ }^{\mathrm{e}}$, Francisco H. Sánchez ${ }^{\mathrm{a}}$, Ricardo A. Dewey ${ }^{\mathrm{b}}$, \\ Marcela B. Fernández van Raap ${ }^{\mathrm{a}, *}$ \\ a Instituto de Física La Plata (IFLP- CONICET), Departamento de Física, Facultad de Ciencias \\ Exactas, Universidad Nacional de La Plata (UNLP), Argentina \\ ${ }^{\mathrm{b}}$ Instituto de Investigaciones Biotecnológicas-Instituto Tecnológico de Chascomús, (IIB- \\ INTECH), CONICET/UNSAM, Chascomús, Argentina \\ 'Instituto de Física “GlebWataghin” (IFGW), Universidade Estadual de Campinas, Brazil \\ ${ }^{\mathrm{d}}$ Institutfür Experimentelle Onkologie und Therapie Forschung Technische Universität München, \\ Germany \\ e Instituto de Investigaciones Bioquímicas de La Plata INIBIOLP, Facultad de Medicina, UNLP, \\ Argentina \\ * Corresponding Author: M. B. Fernández van Raap \\ E. mail address: raap@fisica.unlp.edu.ar \\ Mail address: c.c 67, (1900) La Plata, Argentina. \\ Phone: +542214246062 x 257, Fax +54 2214236335
}




\author{
Present Addresses \\ † INIFTA, Instituto de Investigaciones Fisicoquímicas de La Plata. Argentina \\ †† Centro Regional de Estudios Genómicos, Facultad de Ciencias Exactas, Universidad Nacional de La Plata, Argentina
}

\begin{abstract}
It is known that alternating magnetic field applications on eukaryotic cells loaded with single domain iron oxide nanoparticles result in high hyperthermic citotoxicity leading to cell dead. Although magnetic hyperthermia therapy for cancer tumours is being developed under this idea, some in vitro assays have shown controversial results indicating that alternating magnetic field triggers large apoptotic effect without significant culture-temperature increase. In agreement with these observations a huge lowering in nanoparticle specific heating rates, when going from the colloidal suspension to cell endosomes, together with cell death, has been reported. Here, we propose a new methodology to determine the occurrence of local heating in cells when alternating magnetic fields in the radiofrequency field range are applied to cell cultures holding very low iron oxide concentrations, being these concentrations insufficient to produce a global cell-culture temperature increase up to therapeutic values. To this end, human lung adenocarcinoma cells (A549 cell line) were transduced with a lentiviral vector encoding the expression of the enhanced green fluorescence protein, EGFP, under the action of the inducible human heat shock protein 70B promoter. This modified A549 cell line was incubated with aqueous suspensions of magnetite core nanoparticles (uncoated or covered with coating agents like citric acid or silicon oxide), and exposed to radiofrequency fields. The application of an alternating magnetic field to cell cultures loaded with nanoparticles resulted in no global temperature increase but EGFP expression. Stress-inducible gene expression scales with uptake 2
\end{abstract}


and nanoparticle properties like saturation magnetization and heat dissipation efficiency. Our analysis demonstrates that EGFP expression is linked to a localized intracellular temperature increase.

KEYWORDS magnetic hyperthermia, intracellular heating, iron-oxide nanoparticles, human HSP70B promoter, enhanced green fluorescence protein, radio frequency magnetic field.

\section{Introduction}

Nowadays cancer is one of the main causes of death, with millions of individuals being newly diagnosed every year. The risk of getting cancer before the age of 75 is $18.5 \%$, while the risk of dying from cancer is $10 \%{ }^{1}$. This situation is leading to the development of new diagnosis and therapeutics protocols involving the use of nanoactuators, nanobiodevices and nanoscience methodologies. Oncologic nanotherapies include Magnetic Hyperthermia (MH $)^{2}$, Plasmonic Photothermal Therapy ${ }^{3}$, targeted delivery of anticancer drugs and genes ${ }^{4}$, and Photodynamic Therapy ${ }^{5}$. These new therapies are meant to be less invasive, more efficient and displaying minor side effects.

The MH oncologic therapy is based on the ability of magnetic nanoparticles (MNPs) to induce cancer-cell death upon exposure to an alternating magnetic field (AMF). This AMF is typically of a field driven frequency around $100 \mathrm{kHz}$ and a field amplitude of $15 \mathrm{kA} / \mathrm{m}$. It is believed that cancer cells are killed only when the tumour temperature is raised above $42{ }^{\circ} \mathrm{C}$. Cancer-cell death is due to pathobiological effects such as modification of the normal structures of phospholipids, proteins, and nucleic acids, leading to the deterioration of cell-structure integrity ${ }^{6}$. 
MH therapy is already under clinical trials ${ }^{7}$. Although a great breakthrough has been achieved in many aspects involved in the establishment of this methodology (by itself or combined with more conventional methodologies like radio and chemo therapies), a series of controversial in vitro results have been reported. In these experiments, cell death was achieved without an average global temperature increase of the cell culture ${ }^{8-10}$. For instance, Villanueva et al. ${ }^{8}$ have shown that the application of an AMF $(100 \mathrm{kHz}$ and $12 \mathrm{kA} / \mathrm{m})$ to HeLa tumour cells previously incubated with silica-coated manganese oxide, induced significant cellular damage leading to cell death, although the temperature increase in the cell culture (initially at $37{ }^{\circ} \mathrm{C}$ ) during the $\mathrm{MH}$ treatment was lower than $0.5{ }^{\circ} \mathrm{C}$. Marcos-Campos et al. ${ }^{9}$ have reported a viability decrease from $90 \%$ to $2-5 \%$ in monocyte-derived dendritic cells, previously loaded with positively and negatively charged magnetite nanoparticles (coated with $\mathrm{COOH}-$ or with $\mathrm{NH} 2+$ functional groups), after $30 \mathrm{~min}$ exposure to an AMF of $260 \mathrm{kHz}$ and $13 \mathrm{kA} / \mathrm{m}$. In spite of this, only a temperature increase of $2{ }^{\circ} \mathrm{C}$, over an initial value of $26^{\circ} \mathrm{C}$, was registered. More recently, DiCorato et al. ${ }^{10}$ have carried out systematic measurements of both hyperthermia and magnetic properties in controlled cell environments, using human ovary adenocarcinoma SKOV-3 cells and a wide range of nanomaterials. These authors have reported a systematic fall in the heating efficiency for nanomaterials associated with tumour cells. In agreement with these experiments dealing cells that have internalized the MNPs by unspecific way, similar results have been also shown for in vitro experiments involving more complex receptor-mediated endocytosis process. Creixell et al. ${ }^{11}$ have analysed the internalization of iron oxide nanoparticles coated with carboxymethyldextran and conjugated to epidermal growth factor (EGF) in breast human MDAMB-468 and MCF-7 cells. The binding of EGF to the epidermal growth factor receptor resulted in a significant reduction in cell viability and in a clonogenic survival up to $40 \%$ in a thermal- 
heat dose-dependent manner. It was found that viability reduction further increased up to $99.9 \%$ by $120 \mathrm{~min}$ application of AMF of $233 \mathrm{kHz}$ and $37.5 \mathrm{kA} / \mathrm{m}$, but without a perceptible temperature rise during the experiment. Domenche et al. ${ }^{12}$ have reported the manipulation of lysosome-membrane permeability for selectively killing cancer cells by targeting MNPs to the lysosome and exposing them to an AMF of $233 \mathrm{kHz}$ and $42 \mathrm{kA} / \mathrm{m}$. These authors have suggested that energy dissipated by MNPs associated to lipid membranes under an AMF, leads to the membrane permeabilization. They have also shown that this effect correlates with the production of reactive oxygen species and with a decrease in tumour cell viability. Amstad et al. ${ }^{13}$ have shown that upon AMF application, iron-oxide containing liposomes delivered their cargo, even though the heat released was insufficient to reach membrane melting temperature.

These results cast doubt on the causes and mechanisms involved in cell death during $\mathrm{MH}$ treatments. MNPs dispersed in fluid, gel or solid matrix are known to release heat through Néel and/or Brown relaxation mechanisms when they are exposed to $\mathrm{AMFs}^{14}$. The heat dissipation is related to the out of phase magnetic susceptibility due to the phase lag of the magnetic response behind the applied field. However, cell-internalized MNPs group inside endosomes of about 1-2 $\mu \mathrm{m}$ size, constituting magnetic endosomes which themselves have a resultant magnetic moment. These magnetic endosomes can align in the direction of an applied field forming chains ${ }^{15}$. In this case, the MNPs may locally release heat due to the relaxation of the MNP magnetic moment and/or due to the elastic and viscous response of the cell cytoskeleton to the mechanical rotation and vibration of the magnetic endosome. Microrheology and measurements of the intrinsic strain fluctuations of living cells have shown that the cytoskeleton is a highly dynamic, actively stressed network that can be treated as a course-grained continuum ${ }^{16}$. On the other hand, the 
motion of aligned magnetic endosomes of microbeads engulfed by Dictyostelium cells has been reported $^{15}$.

Although various in vitro experiments have shown cell death without global culture temperature increase, attempts to experimentally determine intracellular temperature increase are rare. Most common techniques for monitoring intracellular temperature use thermosensitive dyes whose fluorescence properties depends on temperature. A temperature probe, based on the thermal decomposition of a thermo-sensitive azobis[N-(2-carboxyethyl)-2-methylpropionamidine] molecule, has been employed to probe the temperature profile at the surface of iron oxide nanoparticle functionalized with poly(ethylene glycol) when they are exposed to AMF. In that setup the fluoresceineamine dye was attached to a thermo labile azo linker and dye release was monitored by photoluminescence ${ }^{17}$. Alternatively, temperature probing has been achieved by monitoring the fluorescence polarization anisotropy of GFP. The method was tested on GFP transfected HeLa and U-87 MG cancer cell lines surrounded by gold nanorods exposed to photothermal heating $^{18}$.

Here, we attempt to fill this point by means of measuring the stress-inducible gene expression in modified A549 cells that express EGFP when internalized with MNPs and exposed to an AMF. The lentiviral vector used to modify A549 cells contains the stress-inducible internal human HSP70B promoter, which directs EGFP expression. These modified A549 cells (from now on $\mathrm{A} 549^{\mathrm{HSP}}$ ) were incubated with different $\mathrm{Fe}_{3} \mathrm{O}_{4}$ MNPs: uncoated (u), citric acid coated (CA), and silicon oxide coated $\left(\mathrm{SiO}_{\mathrm{x}}\right)$; and were exposed to an AMF of $128 \mathrm{kHz}$ and $20.3 \mathrm{kA} / \mathrm{m}$. Flow cytometry analysis was used to monitor temperature-inducible EGFP expression at single-cell level without any additional processing steps. We showed that stress-inducible gene expression in a modified A549 cell line, which has EGFP sequence under the action of HSP70B promoter 6 
(inducible with temperature), is linked to the intracellular MNPs heat dissipation. This link strongly suggests that endocyted MNPs create hot spots inside the cells, even though the amount of heat released is not enough to globally increase the cell culture temperature.

\section{Materials and methods}

\section{Aqueous magnetic suspension synthesis and characterization}

Stable aqueous dispersions of uncoated and citric acid coated magnetite were prepared from iron chlorides as previously described ${ }^{19}$. Briefly, $2.75 \mathrm{~g}$ of $\mathrm{FeCl}_{3} .4 \mathrm{H}_{2} \mathrm{O}$ and $1.01 \mathrm{~g}$ of $\mathrm{FeCl}_{2} \cdot 6 \mathrm{H}_{2} \mathrm{O}$ were dissolved in $50 \mathrm{ml}$ of bidistilled water each, mixed in a three-neck flask, and heated to the reaction temperature of $60{ }^{\circ} \mathrm{C}$. Then, $3 \mathrm{ml}$ of ammonia solution (AS) $\mathrm{NH}_{4} \mathrm{OH}(25 \% \mathrm{w} / \mathrm{w})$ was added drop by drop and left to react for $30 \mathrm{~min}$. After that, $75 \mathrm{ml}$ of AS were added at a rate of $1 \mathrm{drop} / \mathrm{s}$ until the solution reached a $\mathrm{pH}$ of 10.5, high enough to prevent agglomeration due to surface charge. Then, the black precipitate was separated from the dispersion medium with a permanent magnet and resuspended in water at physiological $\mathrm{pH} \sim 7.4$ to get uncoated magnetite $\left(\mathrm{Fe}_{3} \mathrm{O}_{4}\right)$, or mixed with citric acid $(\mathrm{CA})$ aqueous solution $(0.02 \mathrm{~g} / \mathrm{ml})$ at $\mathrm{pH} 4$ and left to react for 90 min at $60{ }^{\circ} \mathrm{C}$ to get citric acid coated magnetite (CA-Fe3O4). Finally, the MNPs were resuspended in water at physiological $\mathrm{pH}$, around 7.4. The surface carboxylate groups provide electrostatic stabilization. Chemical volumetric analysis was used to determine the concentration $[\mathrm{x}]$ of these colloid with an accuracy of $2 \%$. [x] is expressed as magnetite mass per solvent volume. $\mathrm{K}_{2} \mathrm{Cr}_{2} \mathrm{O}_{7}$ was used as titrant.

Silica-iron oxide $\left(\mathrm{SiO}_{\mathrm{x}}-\mathrm{Fe}_{3} \mathrm{O}_{4}\right)$ MNPs were synthesized by means of precipitation of $\mathrm{Fe}(\mathrm{II}) / \mathrm{Fe}(\mathrm{III})$ hydroxide from the aqueous solution of the mixture of $\mathrm{Fe}(\mathrm{II})$ and $\mathrm{Fe}(\mathrm{III})$ salts, 
followed by transformation into magnetite in an oxygen-free atmosphere. The surface coating resulted from the hydrolysis and condensation of tetraethyl orthosilicate (TEOS) and 3(trihydroxysilyl) propylmethylphosphonate (THPMP) and 3-mercaptopropyltrimethoxysilane, yielding a silicon oxide layer with surface phosphonate groups (SiOx/Phosphonate) ${ }^{20,21}$. Briefly, $6.8 \mathrm{~g}$ of ferric chloride hexahydrate and $2.5 \mathrm{~g}$ of ferrous chloride tetrahydrate in $200 \mathrm{ml} \mathrm{ddH}_{2} \mathrm{O}$ water were treated with $15 \mathrm{ml}$ concentrated ammonium hydroxide to obtain a primary precipitate. The material was heated to $90{ }^{\circ} \mathrm{C}$ for $15 \mathrm{~min}$ and then stirred at this temperature for $30 \mathrm{~min}$. To form a coating, $375 \mu \mathrm{l}(1.9 \mathrm{mmol})$ of TEOS was added. After $30 \mathrm{~min}, 750 \mu \mathrm{l}$ of $42 \%$ THPMP solution $(1.3 \mathrm{mmol})$ and $150 \mu \mathrm{l}(0.72 \mathrm{mmol})$ of 3-mercaptopropyltrimethoxysilane were added. The mixture was further treated at $90^{\circ} \mathrm{C}$ for another $30 \mathrm{~min}$, cooled to $25^{\circ} \mathrm{C}$, diluted twice with ethanol, and incubated for $24 \mathrm{~h}$ with continuous stirring. The particles were separated using a magnet and washed twice with ethanol and once with water. The product was sonicated for 10 min. In this way, magnetite nanoparticles coated silicon oxide layer with surface phosphonate groups $\left(\mathrm{SiO}_{\mathrm{x}}-\mathrm{Fe}_{3} \mathrm{O}_{4}\right)$ well dispersed in aqueous solution were obtained. The surface phosphonate groups provide electrostatic stabilization. Colloid concentration was determined spectrophotometrically by forming complexes with 1,10-phenanthroline ${ }^{20}$.

Transmission electron microscopy (TEM) images were measured with a JEOL JEM 2100TEM (acceleration voltage 200 kV, Spot Size 1, Alpha Selector 3) and JEOL JEM 3010 HR-TEM (acceleration voltage $300 \mathrm{kV}$, Spot Size 1, Alpha Selector 3). Samples were prepared by drying the dispersed nanoparticles on a carbon-coated copper grid (ultrathin carbon/holey carbon, 400 mesh cooper grid). The images were acquired with the sample on a single-tilt sample holder using Gatan MSC798 TV camera, Gatan Digital Micrograph and EMMENU programs. 


\section{Alternating magnetic field application}

For AMF application, a field generator consistent of a $2.5 \mathrm{kV}$ power supply and a resonant RLC circuit Hüttinger (2.5/300) was used. The resonator holds an external exchangeable water refrigerated coil. The sample is placed in its centre. For determining the SAR of MNPs in aqueous suspensions a 6-turn coil of $2.5 \mathrm{~cm}$ diameter was used, while for living-cell experiments a 5-turn coil of $7 \mathrm{~cm}$ diameter was used because it was more suitable for placing in its interior a thermal bath at $37^{\circ} \mathrm{C}$ with a Petri dish inside.

To calorimetrically evaluate the SAR of the MNP colloids, a sample of $0.5-1.0 \mathrm{~mL}$ was poured in a clear glass Dewar, and exposed to 128,170 and $260 \mathrm{kHz}$ and field amplitude varying in the range from 16 to $52 \mathrm{kA} / \mathrm{m}$. An optical fiber sensor connected to a calibrated signal conditioner (Neoptix) with an accuracy of $\pm 0.1{ }^{\circ} \mathrm{C}$ was used to measure the colloid temperature during the experiment. The sensor was placed in the center of the sample. Field application was interrupted before reaching $50{ }^{\circ} \mathrm{C}$, in order to minimize solvent evaporation and prevent its destabilization. The SAR values were calculated from the initial slope $\partial T / \partial t$ of experimental heating curves as $S A R=\frac{C_{V}}{[x]} \frac{\partial T}{\partial t}$ where $C_{V}$ is the volumetric heat capacity of the solvent $\left(4.18 \mathrm{~J} / \mathrm{cm}^{3} \mathrm{~K}\right)$ and $[\mathrm{x}]$ the colloid concentration as determined by chemical analysis. $[\mathrm{x}]$ is expressed as magnetite mass per solvent volume. This value was used to normalize magnetization data and to determine experimental SAR values. Each SAR value was determined from three independent experimental heating curves.

\section{Cell culture conditions}


Human lung adenocarcinoma cell line A549 (ATCC, CCL-185) was cultured in Dulbecco's modified Eagle's medium (Gibco, Life Technologies, Denmark) supplemented with $10 \%$ fetal bovine serum, FBS, (NATOCOR, Cordoba, Argentina), 1\% penicillin/streptomycin (Gibco Life Technologies, USA), and 1\% glutamine solution (Gibco Life Technologies, USA), at $37{ }^{\circ} \mathrm{C}$ in a humidified $5 \% \mathrm{CO}_{2}$ incubator, unless specified otherwise.

\section{Lentiviral vector generation}

Cell-free lentiviral supernatants were generated by transient cotransfection of 293T packaging cell line with one of the two transfer vector used in this study (CMV/EGFP or HSP/EGFP, kindly provided by F. Noyan et al. ${ }^{22}$ ), together with the packaging constructs: the Gag/Polexpressing plasmid (pMDLg/pRRE), the Rev-expressing plasmid (pRSV-REV) and the envelope plasmid (pCMV-VSVG), as previously described ${ }^{23}$. Viral titers were determined on A549 cells in the presence of $1 \mathrm{mg} \mathrm{ml}^{-1}$ geneticin for 2 weeks, yielding vector titers of $10^{6}-10^{8} \mathrm{TU}$ (transducing units) $\mathrm{ml}^{-1}$.

\section{Transduction of A549 cell line}

A549 cells were transduced with either CMV/EGFP or HSP/EGFP lentiviral vectors at a multiplicity of infection of 50, for $72 \mathrm{~h}$ in the presence of $8 \mu \mathrm{g} \mathrm{ml}^{-1}$ polybrene (Sigma-Aldrich, St. Louis, USA). After incubation in medium containing $1 \mathrm{mg} \mathrm{ml}^{-1}$ geneticin for 2 weeks, individual neomycin-resistant clones were isolated and subcultured, generating the cell lines A549 ${ }^{\mathrm{CMV}}$ (constitutive EGFP expression) and $\mathrm{A} 549^{\mathrm{HSP}}$ (inducible EGFP expression). Control-induction of EGFP expression in A459 ${ }^{\mathrm{HSP}}$ cell line was achieved by incubating the cells at $43{ }^{\circ} \mathrm{C}$ for $60 \mathrm{~min}$, followed by incubation at $37^{\circ} \mathrm{C}$ for $24 \mathrm{~h}$. EGFP expression was detected by flow cytometry using a FACSCalibur flow cytometer (BD Biosciences).

10 


\section{Cell culture conditions for AMF application}

For AMF application, $\sim 10^{5}$ A549 or A549 ${ }^{\mathrm{HSP}}$ cells were grown in Petri dish (diameter $2.3 \mathrm{~cm}$ ) with $2 \mathrm{ml}$ of medium containing $0.5 \mathrm{mg} \mathrm{ml}^{-1}$ geneticin. When $60 \%$ confluence was reached, cells were washed with phosphate buffered saline (PBS) and incubated for another $17 \mathrm{~h}$ in medium doped with the MNPs at a concentration of $29 \mu \mathrm{g}_{\mathrm{Fe} 2 \mathrm{O} 4} / \mathrm{ml}$. Cells were then washed four times with PBS to remove the non-incorporated MNPs, and medium was replaced. This procedure was carried out with three types of MNPs u- $\mathrm{Fe}_{3} \mathrm{O}_{4}, \mathrm{AC}-\mathrm{Fe}_{3} \mathrm{O}_{4}$ or $\mathrm{SiO}_{x}-\mathrm{Fe}_{3} \mathrm{O}_{4}$. Immediately, the Petri dishes containing the cells internalized with MNPs with the monolayer covered with $1 \mathrm{~mm}$ layer of DMEM, were placed in a double-wall vessel filled with circulating water at controlled temperature of $37^{\circ} \mathrm{C}$, and exposed for $135 \mathrm{~min}$ to an AMF of $128 \mathrm{kHz}$ and $20.3 \mathrm{kA} / \mathrm{m}$. After exposure to the AMF, medium was replaced and the cell cultures were incubated under controlled conditions for $24 \mathrm{~h}$. For cytometry measurements, the cultures were harvested from each dish by trypsination, and fixed with paraformaldehyde (4\%) for 20-25 min, resuspended in PBS, and then stored at $4{ }^{\circ} \mathrm{C}$ until measurements. Cells grown at the same conditions as those of the internalized ones, but without MPNs, were used as control.

\section{Internalization, localization and uptake quantification}

TEM was used to visualize MNPs localization inside the cells. After incubation with magnetic colloids labelling, adhered cells were washed two times with PBS, and then incubated in 2\% glutaraldehyde in phosphate buffer and distillated water for $2 \mathrm{~h}$ at $4{ }^{\circ} \mathrm{C}$. Cells were then postfixed in $1 \% \mathrm{OsO}_{4}$ for $2 \mathrm{~h}$ at $4{ }^{\circ} \mathrm{C}$, washed again with phosphate buffer, dehydrated in an alcohol series, and embedded in Epoxy resin. Ultrathin sections of $60 \mathrm{~nm}$, cut with Reichert-J Super Nova 
ultramicrotome, were examined with a JEOL 1200 EX II transmission electron microscope. Images were acquired with Gatan Erlangshen ES 1000W digital camera.

DC magnetometry was used to determine MNP cell-uptake. Specific magnetization $(M)$ as a function of applied magnetic field $(H)$ at room temperature was obtained using vibrating sample magnetometer (VSM) LakeShore 7404, operated with maximum applied fields $\mu_{0} H_{\max }=1.5 \mathrm{~T}$. For sample preparation, the same growth and incubation protocols as described above were followed but, in order to reach VSM sensitivity, cells were grown in $75 \mathrm{~cm}^{2}$ flasks with $16 \mathrm{ml}$ of medium. After growth and incubation with MNPs, cells were washed, harvested by trypsinization, resuspended in $15 \mathrm{ml}$ of PBS and counted in a Neubauer chamber. From magnetization vs. applied field curves of cells incubated with MNPs and of the same MNPs in aqueous suspensions, the mean uptake $\mathrm{C}$, expressed in $\mathrm{pg} \mathrm{Fe}_{3} \mathrm{O}_{4} /$ cell, was obtained as $10^{15} m_{s}\left(A m^{2}\right) / M_{s}\left(A m^{2} / k_{F_{3} O_{4}}\right) N_{c e l l}$, where $m_{s}$ is the magnetic moment at saturation of the cells incubated with MNPs, $M_{s}$ is the specific saturation magnetization of the MNPs and $N_{\text {cell }}$ is the number of cells in the sample. VSM measurements were carried out on liquid colloid at room temperature to determined $M_{s}$. To this end, $50 \mu \mathrm{L}$ of colloidal suspension were sealed into a heat shrinkable tube to prevent sample evaporation and spills. The so determined colloid magnetic moment was divided by the mass of $\mathrm{Fe}_{3} \mathrm{O}_{4}$ contained in the sealed volume of colloidal suspension.

\section{Statistical analyses}

Comparisons between two samples were performed using Student's $t$ test. $p$-values $<0.05$ were considered statistically significant.

12 


\section{Results and discussion}

The ability of an assembly of MNPs to induce hyperthermia upon exposure to an AMF (driven field frequency $f$ and field amplitude $\mathrm{H}_{0}$ ) depends markedly on their physical properties and on the environment where they are located. In general, the specific absorption rate SAR is a parameter that characterizes the ability of an assembly of MNPs (single magnetic domain), of volume $\mathrm{V}$ and density $\rho$, dispersed in a medium of viscosity $\eta$, to release heat under an AMF.

This parameter is given by: $S A R=\mu_{0} \pi f H_{0}^{2} V \chi^{\prime \prime}(f, \tau)$, where $\mu_{0}$ is the free space permeability $\left(4 \pi 10^{-7} \mathrm{H} / \mathrm{m}\right)$ and $\chi^{\prime \prime}(f, \tau)=\frac{2 \pi f \tau}{1+(2 \pi f \tau)^{2}} \chi_{0}$ is the out-of-phase magnetic susceptibility with $\chi_{0} \cong \frac{\mu_{0} \rho M_{s}^{2} V}{3 k_{B} T}$. Then, besides preset AMF parameters $\left(f\right.$ and $\left.H_{0}\right)$, heating is governed by the MNPs effective relaxation time $\tau$ given by: $\tau^{-1}=\tau_{N}^{-1}+\tau_{B}^{-1}$, where Neél relaxation is due to the switching of the particle magnetic-moment within a time $\tau_{N}=\tau_{0} \exp \left(K_{e} V / k_{B} T\right)$ and Brown relaxation is due to the particle rotation within a time $\tau_{B}=\frac{3 \eta V_{H}}{k_{B} T}$. Clearly, MNPs susceptibility and SAR parameter depend in a complex way on the MNP properties like: size $(D)$, size dispersion, hydrodynamic volume $\left(V_{H}\right)$, saturation magnetization $(M s)$, and effective anisotropy constant $\left(K_{e}\right)$. The uncoated, citric acid coated, and silicon oxide coated MNPs used in this work were synthesized by the co-precipitation method, and their physical properties were determined by TEM, VSM and magnetocalorimetric measurements. 
Mean sizes $<D>$ were derived from size histograms obtained through many TEM images of the MNPs. Representative images and the fitted number log-normal distribution are shown in figure 1 for the three MNPs. Other images and specific data analysis for each MNP are displayed in figures 1, 2, and 3 of Electronic Supplementary Material (ESM). For the three MNP types, crystal planes are observed and electron diffraction (ED) patterns were well indexed with the with a cubic spinel structure, space group $\mathrm{Fd} 3 \mathrm{~m}$ of magnetite and maghemite phases, (see figure 1e). In the case of $\mathrm{SiO}_{\mathrm{x}}-\mathrm{MNPs}$, the thickness of the silica shell, as estimated from the non crystalline flanges observed in TEM images as those shown in figure 3 of ESM, is around $1 \mathrm{~nm}$.

Magnetic characterization shown in figure $2 \mathrm{a}$ indicates that the particles are single magneticdomains, and small enough so that $\mathrm{M}$ vs. $\mathrm{H}$ loops display no hysteresis at room temperature. The loops were well fitted with Langevin functions and accurate $M s$ values were derived from these fits. The $K_{e}$ value was assumed to be the same for the three MNPs used here. Heating curves measured during the application of $128 \mathrm{kHz}$ and $20.3 \mathrm{kA} / \mathrm{m}$ field on the colloidal suspension of concentration [x], listed in table 1, are shown in figure $2 \mathrm{~b}$. The Ms value of CA-MNP is almost half of the magnitude determined for u-MNP, although the MNP sizes of both particles are very close. This result is in agreement with previous work ${ }^{19}$ where we have shown that citric acid coating influence the surface of the iron oxide nanoparticles, producing a larger magnetic frustrated layer, improving nanoparticle stability in the suspension but lowering $M s$ and SAR values. SiOx-MNP falls out of this behaviour, $M S$ is close to magnetite bulk i.e. no frustrated layer appears. The SAR of SiOx-MNP is lower than the SAR of $\mathrm{u}-\mathrm{MNP}$. This is a quite interesting result having $\mathrm{SiOx}-\mathrm{MNP}$ larger size and larger Ms, that may be related to the insulating characteristic of silicon oxide covering layer. 
These particles, displaying distinctive structuring, $M s$, and fluid SAR values, were chosen to experimentally determine the occurrence of intracellular temperature increase in A549 cell culture. The relevant magnetic and structural properties are listed in table 1.

The magnetic susceptibility $\chi^{\prime \prime}(f, \tau)$ appearing in SAR formula, displays a maximum at the condition $2 \pi f \tau=1$. In figure 3, SAR-frequency dependence is exemplified for $\mathrm{SiO}_{x}-\mathrm{Fe}_{3} \mathrm{O}_{4} \mathrm{~A}$ maximum value of $67.3 \mathrm{~W} / \mathrm{g}$ was registered within the available frequency range, at $128 \mathrm{kHz}$, while $\mathrm{CA}_{-} \mathrm{Fe}_{3} \mathrm{O}_{4}$ displays a monotonous increasing behaviour (see figure 2 of ESM), with maximum SAR value measured at $15 \mathrm{~W} / \mathrm{g}$ at $170 \mathrm{kHz}$. With the aim of evaluating intracellular MH by means of assessing EGFP expression, the field parameters that maximize fluid SAR of $\mathrm{SiO}_{x}-\mathrm{Fe}_{3} \mathrm{O}_{4}$ were chosen for in vitro experiments with $\mathrm{A} 549^{\mathrm{HSP}}$ cells loaded with nanoparticles, for each type of MNP.

Once MNPs were well characterized, we proceed to analyze their interactions with the cells. To this end, the amount and location of internalized MNPs were evaluated. Figure 4 shows representative TEM images showing the distribution of the CA-MNPs inside the cell. The particles were incorporated by an unspecific endocytosis process and located inside cytoplasm vesicles. Uptake amounts for the three types of MNPs were determined after $17 \mathrm{~h}$ of incubation with medium doped to $29 \mu \mathrm{g}_{\mathrm{MNP}} / \mathrm{ml}$ of culture medium (DMEM) using dc-magnetometry, as described in Materials and methods section. Different uptake values, listed in table 2, were obtained for the different particles, probably because cell uptake capacity depends on MNP coating. During this process, the particles first bind to the plasma membrane in the form of clusters, later they are engulfed inside the cell. Binding and cluster formation depend on coating 
type and charge ${ }^{24}$. The qualitative uptake, as visualized from TEM images, is consistent with uptake values measured with dc magnetometry.

Then, thermal induction of gene expression in A549 ${ }^{\mathrm{HSP}}$ cells was assessed by detecting EGFP expression after treatments at 37,39 and $43{ }^{\circ} \mathrm{C}$ for $60 \mathrm{~min}$, using flow cytometry analysis. The percentage of cells expressing EGFP (\% EGFP) linearly increases with temperature to reach a maximum of about $80 \%$ at $43{ }^{\circ} \mathrm{C}$, relative to EGFP expression of untreated cells. Results are shown in figure 5, together with representative optical and fluorescence images and a representative flow cytometry dot plot. This analysis confirms that thermal stress is able to induce EGFP expression in A549 ${ }^{\mathrm{HSP}}$ cells, and this induction is greatly increased at $43{ }^{\circ} \mathrm{C}$, as previously reported ${ }^{22}$.

Figure 6 shows the results of experiments carried out to determine whether exposure to an AMF or MNP incorporation into the cell endosomes could induce stress by themselves. The percentages of cells expressing EGFP after exposure to an AMF (128 kHz and $20.3 \mathrm{kA} / \mathrm{m})$ during $\mathrm{t}_{\mathrm{a}}=15,30,60,135,150$ y 180 minare shown in figure $6 a$. For $\mathrm{t}_{\mathrm{a}} \leq 60 \mathrm{~min}$ the increase in $\%$ EGFP (relative to negative control) was lower than $2 \%$. For $t_{a}=180$ min the increase of EGFP was about $25 \%$, while for times shorter than 135 min the increases were below $8 \%$.Regarding MNP-uptake experiments, the percentages of cells expressing EGFP after incubation with 5, 18, 29, 58 y $116 \mu g_{F e 3 O 4} / m_{D M E M}$ of $\mathrm{SiO}_{x}-\mathrm{Fe}_{3} \mathrm{O}_{4}$ colloidal suspension are shown in figure $6 \mathrm{~b}$. When incubating with $58 \mu g_{F e 3 O 4} / \mathrm{ml}_{D M E M}$, an increase of EGFP, relative to negative control, of about 23 $\%$ was observed. Therefore, to avoid induction originated by exposure to an AMF itself or by MNP uptake itself, we have chosen $29 \mu g_{F e 3 O 4} / m l_{D M E M}$ as a suitable concentration for incubation and AMF exposing times shorter than $150 \mathrm{~min}$.

16 
Finally, to evaluate the occurrence of intracellular $\mathrm{MH}$ in $\mathrm{A} 549^{\mathrm{HSP}}$ cells loaded with $\mathrm{Fe}_{3} \mathrm{O}_{4}, \mathrm{AC}$ $\mathrm{Fe}_{3} \mathrm{O}_{4}$ or $\mathrm{SiO}_{\mathrm{x}}-\mathrm{Fe}_{3} \mathrm{O}_{4} \mathrm{MNPs}$, the following procedure was carried out. Cells were grown as monolayer in 5 Petri dishes, and the percentage of EGFP was evaluated in: 1) cells treated for 60 min at $43{ }^{\circ} \mathrm{C}$ (positive control) to corroborate that the promoter was properly working; 2 ) cells incubated without MPNs and not exposed to any AMF or thermal treatment (negative control),to be aware of any random unpredictable source of stress; 3) cells incubated for $17 \mathrm{~h}$ in medium doped with the MNPs at a concentration of $29 \mu g_{F e 3 O 4} / m l_{D M E M}$ and not exposed to any AMF or thermal treatment (MNPs-control); 4) cells exposed to an AMF for 135 min without MNPs incubation or any thermal treatment (AMF-control); and 5) cells incubated with MNPs at a concentration of $29 \mu g_{\mathrm{Fe} 3 \mathrm{O}} / \mathrm{ml}_{\mathrm{DMEM}}$ and exposed to an AMF of $128 \mathrm{kHz}$ and $20.3 \mathrm{kA} / \mathrm{m}$ for 135 $\min (\mathrm{MH}-\mathrm{experiment})$. This procedure was carried out with the three different MNPs: $\mathrm{Fe}_{3} \mathrm{O}_{4}$, $\mathrm{CA}-\mathrm{Fe}_{3} \mathrm{O}_{4}$ and $\mathrm{SiO}_{x}-\mathrm{Fe}_{3} \mathrm{O}_{4}$, in duplicate.

Culture temperature was sensed during the whole exposure time to the AMF and no temperature increase was registered in any experiment, consistently with previous results discussed in the introduction. Then, intracellular SAR cannot be magneto-calorimetrically established.

Results of the percentage of EGFP expressing cells for these five cell cultures (controls and $\mathrm{MH}$ experiment) for the three MNPs are shown in figure 7. The basal levels of EGFP expression in the negative control cells were similar to the values seen in the AMF-control $(p=0.75231)$, and to the percentage of EGFP expression observed in cells treated with all three MNPs-controls: $\mathrm{Fe}_{3} \mathrm{O}_{4}$ $(p=0.99525), \mathrm{AC}_{-} \mathrm{Fe}_{3} \mathrm{O}_{4}(p=0.48913)$, and $\mathrm{SiO}_{\mathrm{x}}-\mathrm{Fe}_{3} \mathrm{O}_{4}(p=0.59582)$. These results indicated that neither the field nor the particle uptake induced stress by themselves. Contrarily, cells incubated with all of the three types of MNPs and exposed to the AMF (HM-experiment) shown 
statistically significant differences in the percentage of EGFP expressing cells compared to the cells treated with the same MNPs (p equal to $0.02253,0.00275$, and 0.06674 for $\mathrm{u}_{-} \mathrm{Fe}_{3} \mathrm{O}_{4}, \mathrm{SiO}_{\mathrm{x}^{-}}$ $\mathrm{Fe}_{3} \mathrm{O}_{4}$, and $\mathrm{AC}-\mathrm{Fe}_{3} \mathrm{O}_{4}$, respectively), and compared to the corresponding AMF controls (p equal to $0.00286,0.00162$ and 0.0102 for $\mathrm{Fe}_{3} \mathrm{O}_{4}, \mathrm{SiO}_{\mathrm{x}}-\mathrm{Fe}_{3} \mathrm{O}_{4}$, and $\mathrm{AC}-\mathrm{Fe}_{3} \mathrm{O}_{4}$, respectively). These results gave evidence that the HSP70B promoter was able to increase EGFP gene expression upon MNP-driven hyperthermia.

Subsequently, we analyzed gene expression induction in culture cells incubated with the three types of MNPs and exposed to AMF, using the distinctive MNPs physical parameters and SAR behaviour.

Although the amount of heat dissipated in the cell cultures was not enough to significantly raise the cell culture temperature to allow the calorimetric measure of the intracellular SAR, we found a correlation between SAR measured in the aqueous suspension and the percentage of loaded A549 ${ }^{\mathrm{HSP}}$ cells expressing EGFP after exposure to the AMF. The larger the SAR value, the larger the \% EGFP (see figure 8a). Assuming that these SAR values holds in the cell environment, the total heat dose (THD) expressed in joules per cell ${ }^{25}$ was calculated using SAR values at a given magnetic-field frequency and amplitude, the application time $t_{a}$, and the mass of internalized nanoparticles per cell $(\mathrm{C})$ as: $\mathrm{THD}=\mathrm{C} \times \mathrm{SAR} \times \mathrm{t}_{\mathrm{a}}$. Using uptake values $\mathrm{C}$ determined with a dc magnetometer, listed in table 2, THD values of $1.16,4.08$ and $15.32 \mu \mathrm{J} /$ cell were obtained for $A C$ - , $\mathrm{SiO}_{x^{-}}$and u- MNPs, respectively. Figure $8 \mathrm{~b}$ shows that the percentage of loaded A549 ${ }^{\mathrm{HSP}}$ cells expressing EGFP after exposure to the AMF increases with THD, i.e. the \% EGFP increases with the mean energy released per cell. It can be notice that the relation between the \% EGFP and THD is not linear. A linear relation could have been expected having in mind the 
linear relation obtained for homogeneous heating of A549 ${ }^{\mathrm{HSP}}$ cells in thermal bath shown in figure 5. However, saturation in the dependence of \% EGFP vs. THD is expected because once a cell absorbs the minimum energy needed to express, a further increase in the energy will have no influence in its expression. The maximum \% EGFP achieved being lower that $100 \%$ may be related to the inhomogeneous distribution of the MNPs among the cells and in the cell itself. The uptake as measured with VSM is a mean uptake value, actually some cells may be having no MNP incorporated while others may be having large amount of MNPs distributed in many endosomes as it was exemplified in figure 4 for AC-MNPs. Both, the number of filled endosome and their sizes vary within a culture and the compactness of the MNPs inside the endosomes also varies when the MNP is changed. Particularly, less dense endosomes are observed for CA-MNP than for u-MNP. TEM image of A549 cell incubated with u-MNP is shown figure 5 of ESM.

In general, the total heat released by the MNPs in a cell must be proportional to the amount of MNPs incorporated by the cell, i.e. proportional to the uptake. It must be also proportional to the capacity of these MNPs to absorb energy from the field and release it into the cell, and to the exposure time. Then, the \% EGFP appears as an extensive quantity, which is made intensive dividing it by $\mathrm{C}$. On the other hand, at fixed AMF conditions SAR is proportional to $V M_{s}^{2} \chi^{\prime \prime}(\tau)$, i.e. it depends explicitly on the relaxation mechanism through the relaxation time. However, in the case of our particles, the distinctive parameter driving specific heat dissipation is $M s$. In figure $8 \mathrm{c}$ the plot of $\% \mathrm{EGFP} / \mathrm{C} v s . \mathrm{VMs}{ }^{2}$ displays an increasing behaviour. Recalling that the EGFP expression is due to a thermally-induced stress, as shown in figure 5, the increasing behaviour of \%EGFP/C vs. $\mathrm{VM} s^{2}$ suggests that intracellular heat release is occurring, even though the total amount of heat released is not enough to globally increase the temperature of the cell culture. Alternatively, the \%EGFP can be plotted vs. CxMs, being this quantity the mean 19 
magnetic moment of a cell at saturation: $\left\langle\mu_{\mathrm{sat}}>=\mathrm{N}_{\mathrm{p}} \mathrm{V} \rho M s\right.$, where $\mathrm{N}_{\mathrm{p}}$ is the mean number of particles incorporated per cell. Again, an increasing behaviour is obtained (see figure 8d) reinforcing the idea of a direct relationship between the percentage of cells expressing EGFP and the intracellular THD and consequently to SAR.

\section{Conclusions}

In vitro experiments were performed with human lung adenocarcinoma cells (A549 cell line) modified with a lentiviral vector that encodes EGFP under the action of the human HSP70B promoter. This modified A549 cell line was incubated with three suspensions of magnetite nanoparticles displaying distinctive size, saturation magnetization and specific response to alternated magnetic fields. Distinctive properties of the same core material were achieved using uncoated as well as silicon oxide or citric acid coated nanoparticles. Here we have shown that the application of an alternating magnetic field, in the radiofrequency range, to culture cells loaded with nanoparticles, resulted in thermal-induced gene expression in the absence of a global temperature increase. Stress-inducible gene expression, measured as the amount of cell expressing EGFP, increased with the mean magnetic moment of a cell at saturation, with nanoparticle volume times the square of saturation magnetization nanoparticle, with thermal heat dose and also with nanoparticle heat dissipation ability recorded in the fluid state. All of these dependences are linking gene expression to a localized intracellular temperature increase. 
Electronic Supplementary Material: Additional HR-TEM and ED images and the corresponding size histograms, SAR frequency dependence and TEM images of A549 cell with an endosome loaded with MNPs. This material is available free of charge via the Internet at http://pubs.acs.org/.

\section{Acknowledgements}

This work has been funded by CONICET (PIP 00720), ANPCyT (PICT 00898), UNLP-X11/680 grants of Argentina.; TEM at Brazilian Nanotechnology National Laboratory (LNNano), Centro Nacional de Pesquisa em Energia e Materiais (CNPEM), Brazil under the project TEM-MSC14825. We thank Cátedra de Patología B - CONICET for allowing the use of cell culture lab, help in cell culture handling and kind suggestions on biological issues, Roxana Peralta for extreme care with cell sample preparation for TEM. P. Mendoza Zélis, F. H. Sánchez, R. A. Dewey, R. G. Goya, and M. B. Fernández van Raap are members of CONICET, and M. E. de Sousa and A. Carrea are fellows of CONICET, Argentina.

\section{References}

[1] Ferlay J, Soerjomataram I, Ervik M, Dikshit R, Eser S, Mathers C, Rebelo M, Parkin DM, Forman D, Bray, F. GLOBOCAN 2012 v1.0, Cancer Incidence and Mortality Worldwide: IARC CancerBase No. 11 [Internet]. Lyon, France: International Agency for Research on Cancer; 2013. Available from: http://globocan.iarc.fr, accessed on day/month/year.

[2] Dutz S., Hergt R.. Nanotechnology, Magnetic particle hyperthermia-a promising tumour therapy?. Nanotechnology, 2014, 25, 452001(28pp). 
[3] Huang X, Jain PK, El-Sayed IH, El-Sayed MA., Plasmonic photothermal therapy (PPTT) using gold nanoparticles. Lasers Med Sci, 2008, 23, 217-228.

[4] Ganta S, Devalapally H, Shahiwala A, Amiji M., A review of stimuli-responsive nanocarriers for drug and gene delivery. Journal of Controlled Release, 2008, 126, 187-204.

[5] Sasidharan Swarnalatha Lucky, Khee Chee Soo, and Yong Zhang, Nanoparticles in Photodynamic Therapy. Chem. Rev., 2015, 115 (4), 1990-2042.

[6] Hilger I., In vivo applications of magnetic nanoparticle hyperthermia. Int J Hyperthermia, 2013, 29(8): 828-834.

[7] Luo S, Wang LF, Ding WJ, Wang H, Zhou JM, Jin HK, Su SF, Ouyang WW. Clinical trials of magnetic induction hyperthermia for treatment of tumours. OA Cancer, 2014, 18;2(1):2.

[8] Villanueva A., de la Presa P., Alonso J. M., Rueda T., Martínez A., Crespo P., Morales M. P., Gonzalez-Fernandez M. A., Valdés J., Rivero G., Hyperthermia HeLa Cell Treatment with Silica-Coated Manganese Oxide Nanoparticles. J. Phys. Chem. C, 2010, 114, 1976-1981.

[9] I Marcos-Campos, L Asín, T E Torres, C Marquina, A Tres, M R Ibarra, G F Goya. Cell death induced by the application of alternating magnetic fields to nanoparticle-loaded dendritic cells. Nanotechnology, 2011, 22, 205101 (13pp).

[10] Di Corato R., Espinosa A., Lartigue L., Tarahud M., Chat S., Pellegrino T., Menager C., Gazeau F., Wilhelm C.. Magnetic hyperthermia efficiency in the cellular environment for different nanoparticle designs. Biomaterials, 2014, 35, 6400-6411.

[11] Creixell M., Bohorquez A. C., Torres-Lugo M., and Rinaldi C., EGFR-targeted magnetic nanoparticle heaters kill cancer cells without a perceptible temperature rise. ACS Nano, 2011, 5, 7124-7129.

[12] Domenech M., Marrero-Berrios I., Torres-Lugo M., Rinaldi C.. Lysosomal Membrane Permeabilization by Targeted Magnetic Nanoparticles in Alternating Magnetic Fields, ACSNano, 2013, 7(6) 5091-5101.

[13] Amstad, E.; Kohlbrecher, J.; Muller, E.; Schweizer, T.; Textor, M.; Reimhult, E. Triggered Release from Liposomes through Magnetic Actuation of Iron Oxide Nanoparticle Containing Membranes. NanoLett, 2011, 11, 1664-1670.

[14] Rosensweig R. E., Heating Magnetic Fluid With Alternating Magnetic Field. J. Magn. Magn. Mater., 2002, 252, 370-374.

[15] Wihelm C., Out-of-Equilibrium Microrheology inside Living Cells, Phys Rev Lett, 2008, 101, 028101(4pp). 
[16] Lau A.W. C., Hoffman B. D., Davies A., Crocker J. C., Lubensky T. C.. Microrheology, Stress Fluctuations, and Active Behavior of Living Cells, Phys Rev Lett, 2003, 91 (19), 198101(4pp).

[17] Riedinger A., Guardia P., Curcio A., Garcia M. A., Cingolani R., Manna L., Pellegrino T., Subnanometer Local Temperature Probing and Remotely Controlled Drug Release Based on Azo-Functionalized Iron Oxide Nanoparticles. Nano Lett. 2013, 13, 2399-2406.

[18] Donner J. S., Thompson S. A., Kreuzer M. P., Baffou G.,and Quidant R., Mapping Intracellular Temperature Using Green Fluorescent Protein. Nano Lett. 2012, 12, 2107-2111

[19] de Sousa M. E., Fernández van Raap M. B.; Rivas P. C.; Mendoza Zélis P.; Girardin P., Pasquevich G., Alessandrini J., Muraca D., Sánchez F. H.. Stability and Relaxation Mechanisms of Citric Acid Coated Magnetite Nanoparticles for Magnetic Hyperthermia. J. Phys. Chem. C. 2013, 117 (10), 5436-5445.

[20] Mykhaylyk O., Sobisch T., Almstätter I., Sanchez-Antequera Y., Brandt S., Anton M., Döblinger M, Eberbeck D., Settles, Rickmer Braren M, et. al. Silica-Iron Oxide Magnetic Nanoparticles Modified for Gene Delivery: A Search for Optimum and Quantitative Criteria. Pharm Res, 2012, 29(5), 1344-1365.

[21] Mykhaylyk O, Sanchez-Antequera Y, Vlaskou D, Hammerschmid E, Anton M, Zelphati O, Plank C. Liposomal magnetofection. Meth Mol Biol., 2010, 605, 487-525.

[22] Noyan F, Avedillo Díez I, Hapke M, Klein C, Dewey R A. Induced transgene expression for the treatment of solid tumors by hematopoietic stem cell-based gene therapy. Cancer Gene Ther. 2012, 5, 352.

[23] Schambach A, Bohne J, Chandra S, Will E, Margison GP, Williams DA, Baum C.. Equal potency of gammaretroviral and lentiviral SIN vectors for expression of O6-methylguanine-DNA methyltransferase in hematopoietic cells. Mol. Ther, 2006, 13, $391-400$.

[24] Wilhelm C., Gazeau F. Universal Cell Labelling With Anionic Magnetic Nanoparticles. Biomaterials, 2008, 29, 3161-3174.

[25] DeNardo, S. J.; DeNardo, G. L.; Natarajan, A.; Miers, L. A.; Foreman, A. R.; Gruettner, C.; Adamson, G. N.; Ivkov, R. Thermal Dosimetry Predictive of Efficacy of 111In-ChL6 Nanoparticle AMF-Induced Thermoablative Therapy for Human Breast Cancer in Mice. J. Nucl. Med., 2007, 48, 437-444. 


\section{Figures}

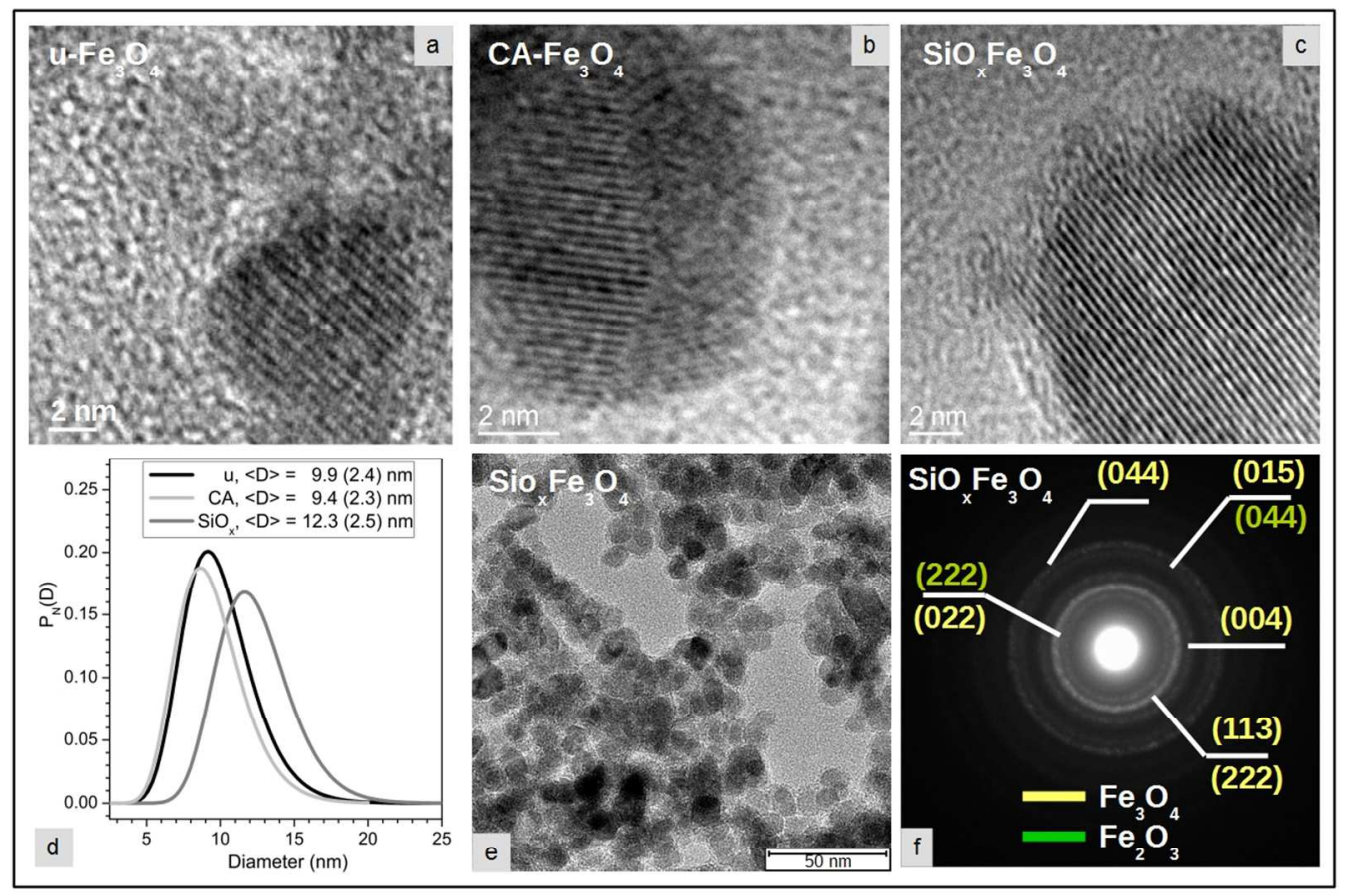

Figure 1: TEM micrographs showing single magnetic particle a) uncoated $\left(\mathrm{u}-\mathrm{Fe}_{3} \mathrm{O}_{4}\right.$, $)$ b) citric acidcoated $\left(\mathrm{CA}-\mathrm{Fe}_{3} \mathrm{O}_{4}\right)$, and c)silicon oxide coated $\left.\left(\mathrm{SiO}_{\mathrm{x}}-\mathrm{Fe}_{3} \mathrm{O}_{4}\right) \cdot \mathrm{d}\right)$ Fitted number size distribution (log- normal) of histograms obtained by measuring more than 120 particles, mean diameter and standard deviation (in parentheses) are indicated. e) Panoramic image for SiOxcoated MNPs. f)Electron diffraction pattern of SiOx coated MNP indexed with the reflection lines of magnetite. 

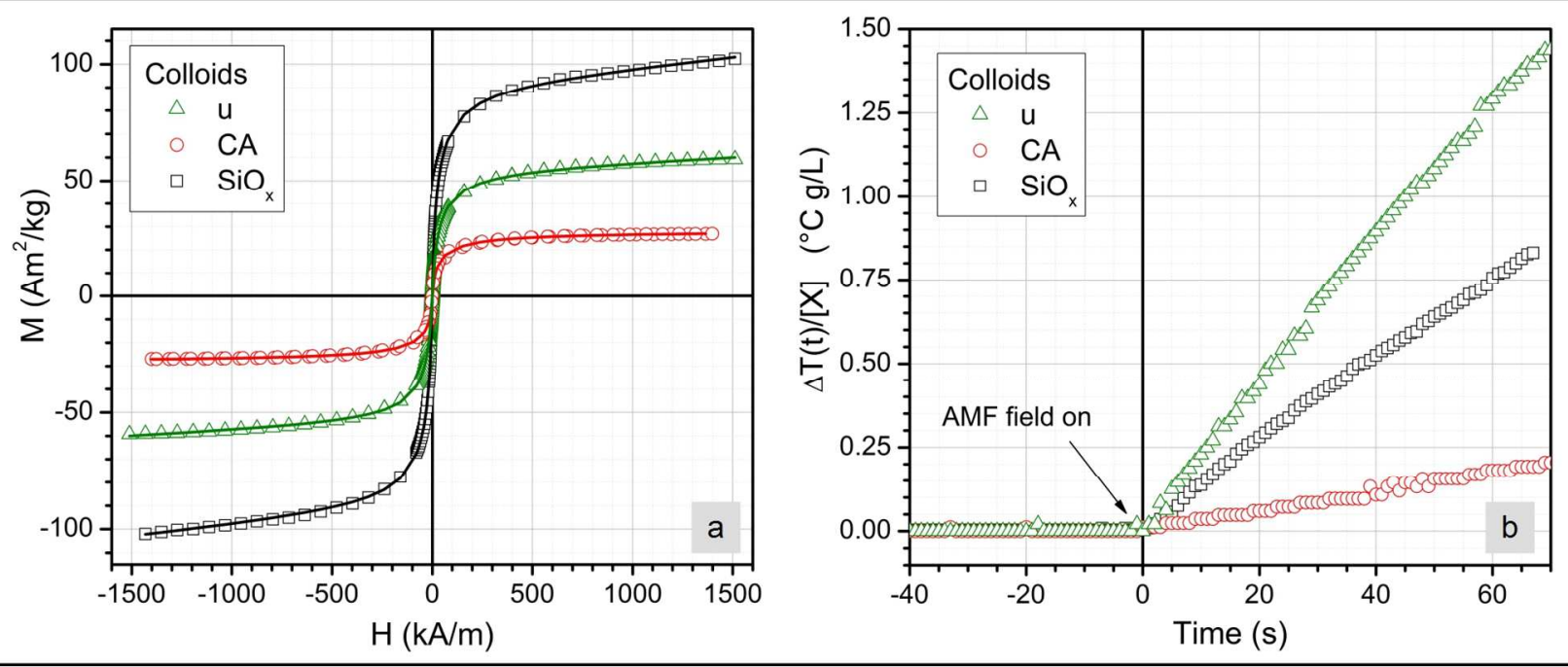

Figure 2: a) Room temperature specific magnetization $(\mathrm{M})$ vs. applied field $(\mathrm{H})$ loops recorded with VMS- dc magnetometry, data was normalized by mass of $\mathrm{Fe}_{3} \mathrm{O}_{4}$. b) Heating curves of MNPs aqueous suspensions measured at $128 \mathrm{kHz}$ and $20.3 \mathrm{kA} / \mathrm{m}$. Data is plotted as temperature increase $\Delta \mathrm{T}$ scaled with concentration $[\mathrm{x}]$ vs. time.

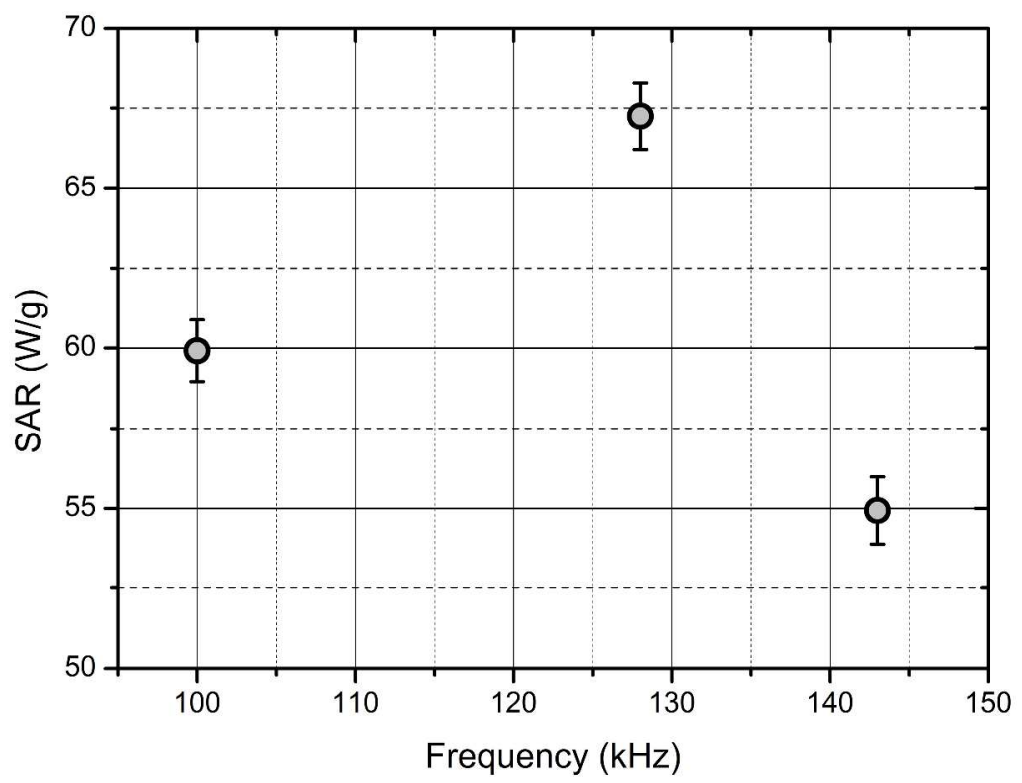


Figure 3: SAR values in $\mathrm{SiOx}-\mathrm{Fe}_{3} \mathrm{O}_{4}$ aqueous suspensions vs. driven field frequency at a fixed field amplitude of $20.3 \mathrm{kA} / \mathrm{m}$.

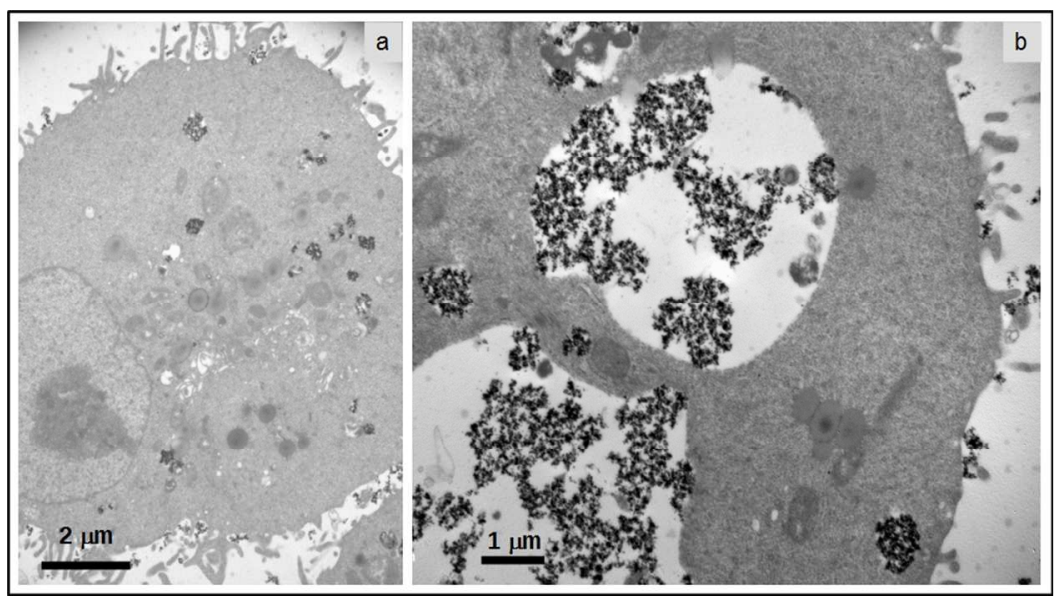

Figure 4: Nanoparticle-cell interaction characterization. Representative TEM images showing:

a) the distribution of AC-MNPs inside A549 cell and b) details of MNPs distribution in the cell. 

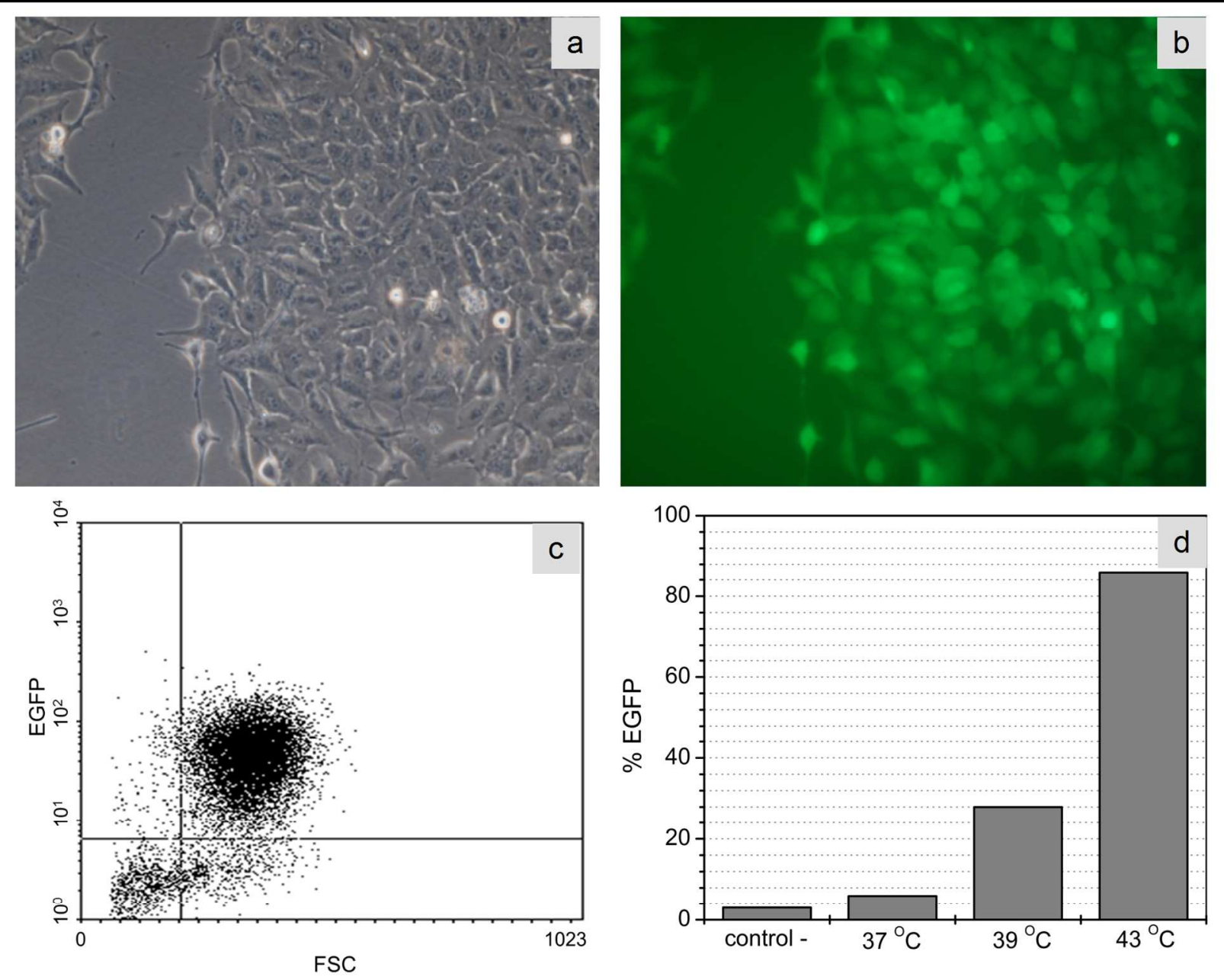

Figure 5: Thermal stress characterization of modified $\mathrm{A} 549^{\mathrm{HSP}}$ cells. a) Phase contrast microscopy image $(20 \mathrm{X})$ of $\mathrm{A} 549^{\mathrm{HSP}}$ cells after treatment at $43{ }^{\circ} \mathrm{C}$ for 60 minin a thermal bath. b)Fluorescent microscopy image of the $\mathrm{A} 549^{\mathrm{HSP}}$ cells shown in a).c) Flow cytometry dot-plot showing EGFP expression vs. forward scattered (FSC). d) $\%$ EGFP is the percentage (relative to the total analyzed cells) of cells expressing EGFP, in A549 ${ }^{\mathrm{HSP}}$ cultures treated at 37,39 and $43{ }^{\circ} \mathrm{C}$ for $60 \mathrm{~min}$. Control - stands for negative control, i.e. untreated cells. 


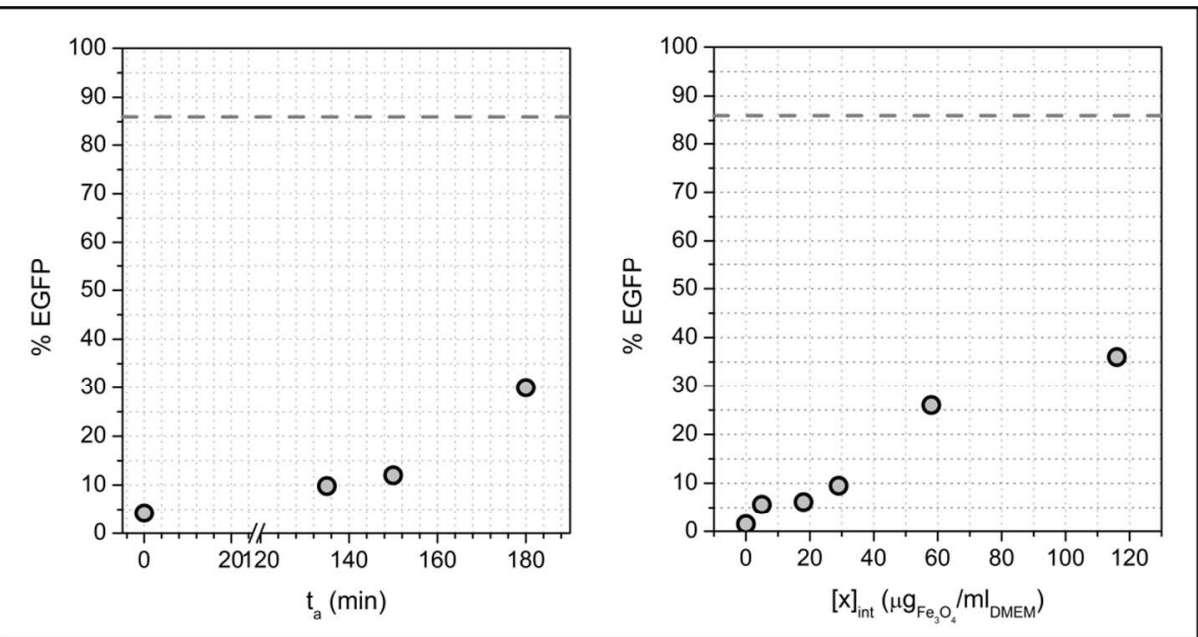

Figure 6: Characterization of alternating magnetic field and nanoparticles gene stress induction. Percentage of cells expressing EGFP (\%EGFP) a) after exposure of unloaded A549 ${ }^{\mathrm{HSP}}$ cells to an AMF of $128 \mathrm{kHz}$ and $20.3 \mathrm{kA} / \mathrm{m}$ for time intervals $t_{\mathrm{a}}$, and $\mathrm{b}$ ) after incubation of A549 ${ }^{\mathrm{HSP}}$ cells in medium doped with $\mathrm{SiO}_{x}-\mathrm{Fe}_{3} \mathrm{O}_{4}$ colloidal suspension of concentration [x] $]_{\text {int. For comparison, the }}$ value of thermal treatment at $43^{\circ} \mathrm{C}$ for $1 \mathrm{~h}$ is included (dotted lines). 

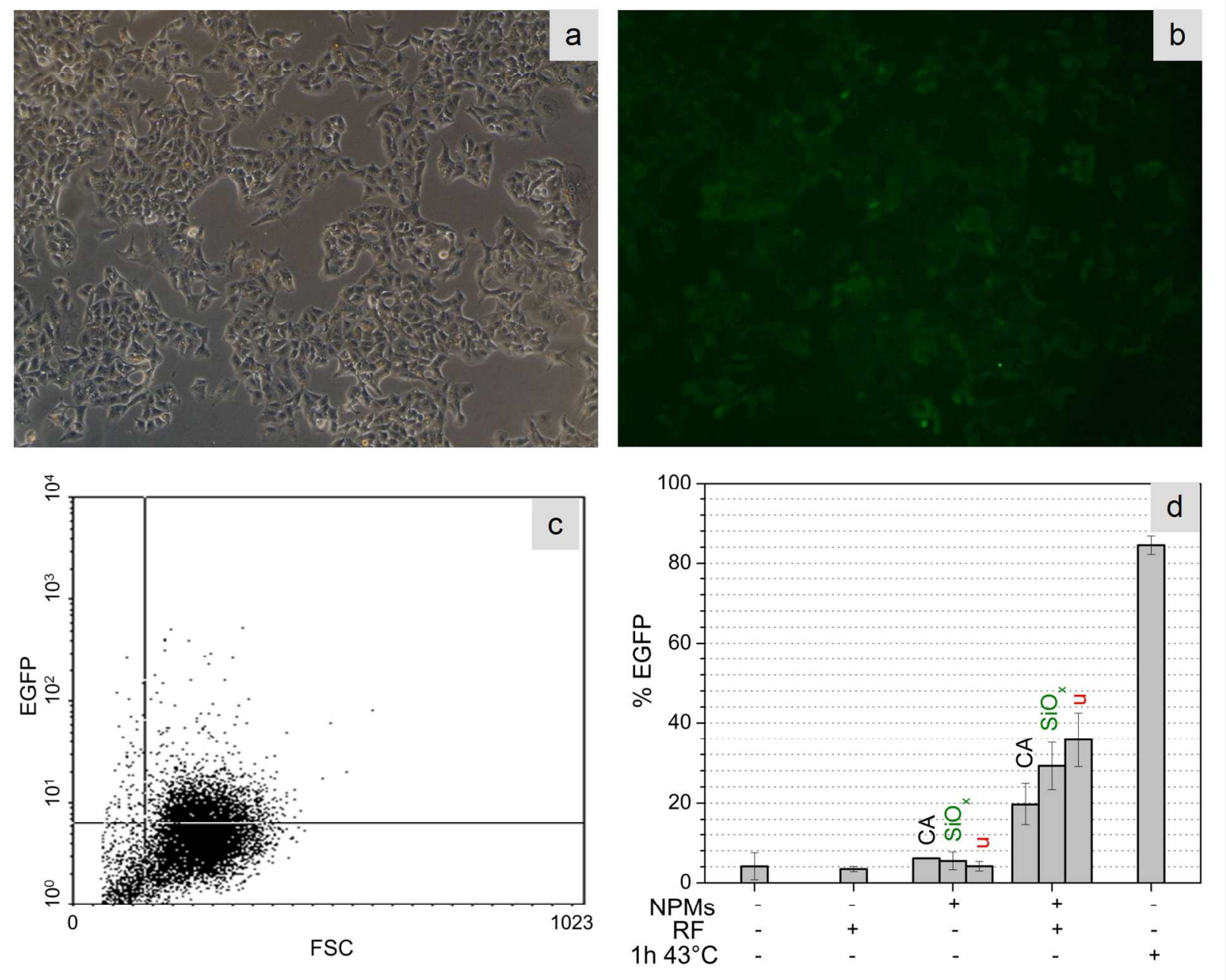

Figure7:a) Phase contrast microscopy image $(20 \mathrm{X})$ of $\mathrm{A} 549^{\mathrm{HSP}}$ cells after incubation with MNPs and AMF treatment. b)Fluorescent microscopy image of the A549 ${ }^{\mathrm{HSP}}$ cells shown in a).c) Flow cytometry dotplot showing EGFP expressing cells vs. forward scattered (FSC). d) Bar graph displaying the percentages of cells expressing EGFP (\%EGFP) in A549 ${ }^{\mathrm{HSP}}$ cell culture, from left to right, incubated without MPNs and not exposed to any AMF or to thermal treatment (negative control), cells exposed to an AMF of $128 \mathrm{kHz}$ and $20.3 \mathrm{kA} / \mathrm{m}$ (AMF-control) for135 min, cells incubated for $17 \mathrm{~h}$ in medium doped with MNPs at a concentration of $29 \mu g_{F e 3 O 4} / \mathrm{ml}_{D M E M}$ (MNPs-control), cells incubated with MNPs at a concentration of $29 \mu g_{F e 3 O 4} / m l_{D M E M}$ and exposed to an AMF of $128 \mathrm{kHz}$ and $20.3 \mathrm{kA} / \mathrm{m}$ for $135 \mathrm{~min}$ (HM-experiment), and cellstreated in 29 
thermal bath at $43{ }^{\circ} \mathrm{C}$ for $60 \mathrm{~min}$ (positive control). Data is shown as mean $\pm \mathrm{SD}$ of two independent experiments, and statistically analyzed using Student's $t$ test.

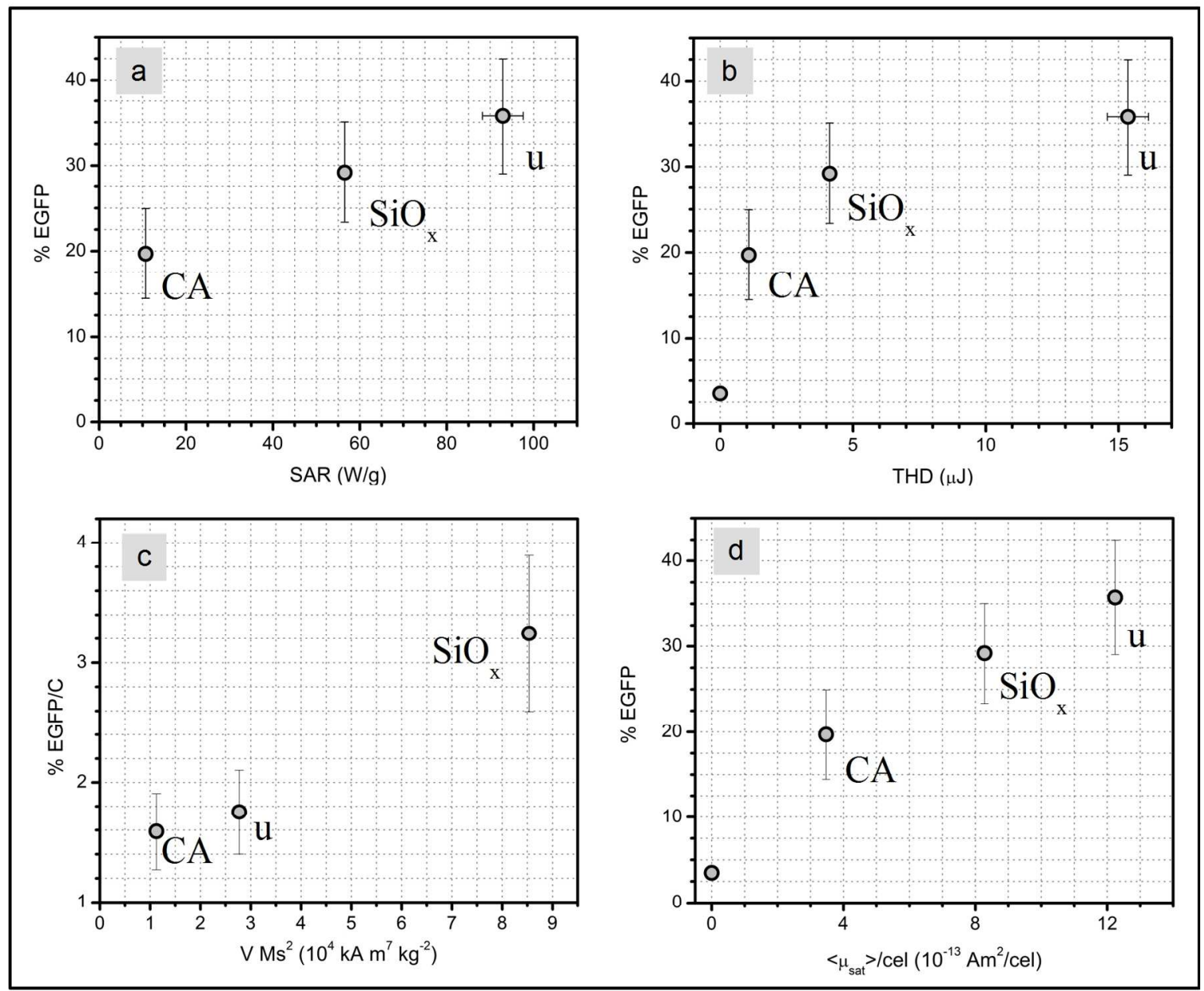

Figure 8: Percentage of cells expressing EGFP (\%EGFP)vs. a)SAR; b) total heat dose (THD) per cell, i.e. MNP energy released per cell due to exposure to an AMF(data from control AMF culture is included with null assigned energy).c)Specific variable \%EGFP/C defined as \% EGFP divided by the uptake $\mathrm{C} v s$. the square of nanoparticle saturation magnetization $(M s)$ times the MNP volume (V). d) Percentage of cells expressing EGFP (\% EGFP) vs. the mean magnetic moment of a cell at saturation, $<\mu_{\mathrm{sat}}>$. 
Tables

\begin{tabular}{|c|c|c|c|c|}
\hline $\mathrm{MNP}$ & $\begin{array}{c}{[\mathrm{x}]} \\
\left(\mathrm{mg}_{\mathrm{MNP}} / \mathrm{ml}\right)\end{array}$ & $\begin{array}{c}\mathrm{D}> \\
\mathrm{nm}\end{array}$ & $\begin{array}{c}\mathrm{Ms} \\
\left(\mathrm{Am}^{2} / \mathrm{kg}\right)\end{array}$ & $\left(\mathrm{W} / \mathrm{g}_{\mathrm{MNP}}\right)$ \\
\hline $\mathrm{CA}-\mathrm{Fe}_{3} \mathrm{O}_{4}$ & 8.3 & 9.4 & 28 & $10.7(0.6)$ \\
\hline $\mathrm{u}-\mathrm{Fe}_{3} \mathrm{O}_{4}$ & 4.8 & 9.9 & 60 & $92.9(4.5)$ \\
\hline $\mathrm{SiO}_{\mathrm{x}}-\mathrm{Fe}_{3} \mathrm{O}_{4}$ & 22.5 & 12.3 & 92 & $67.3(1.0)$ \\
\hline
\end{tabular}

Table 1: Colloid and nanoparticle properties.MNP: type of magnetic nanoparticle,[x] is the concentration expressed in $\mathrm{mg}$ of $\mathrm{Fe}_{3} \mathrm{O}_{4}$ per $\mathrm{mL}$ of water, $<\mathrm{D}>$ is the mean MNP size determined from HRTEM histograms shown in the ESM, $M s$ : saturation magnetization expressed per mass of $\mathrm{Fe}_{3} \mathrm{O}_{4}$, and SAR: specific absorption rate measured in the colloidal suspensions at $128 \mathrm{kHz}$ and $20.3 \mathrm{kA} / \mathrm{m}$.

\begin{tabular}{|c|c|c|c|c|c|}
\hline $\mathrm{MNP}$ & $\mathrm{C}$ & EGFP & EGFP/C & $\mathrm{Cx} M s=<\mu_{\text {sat }}>/$ cell & THD \\
& $(\mathrm{pg} / \mathrm{cell})$ & $(\%)$ & $(\mathrm{cell} / \mathrm{pg})$ & $\left(10^{-15} \mathrm{Am}^{2} /\right.$ cell $)$ & $(\mu \mathrm{J} /$ cell $)$ \\
\hline $\mathrm{CA}-\mathrm{Fe}_{3} \mathrm{O}_{4}$ & $12.4(2.5)$ & $20(5)$ & $1.6(0.5)$ & 347 & $1.16(0.06)$ \\
\hline $\mathrm{u}-\mathrm{Fe}_{3} \mathrm{O}_{4}$ & $20.4(4.1)$ & $36(7)$ & $1.8(0.4)$ & 1224 & $15.32(0.08)$ \\
\hline $\mathrm{SiO}_{\mathrm{x}} \mathrm{Fe}_{3} \mathrm{O}_{4}$ & $9.0(1.8)$ & $29(6)$ & $3.2(0.9)$ & 828 & $4.08(0.08)$ \\
\hline
\end{tabular}

Table 2: Nanoparticle-cell interaction and interrelation between EGFP and the physical characterization. $\mathrm{C}$ is the $\mathrm{A} 549^{\mathrm{HSP}}$ uptake after $17 \mathrm{~h}$ incubation in $29 \mu \mathrm{g} / \mathrm{ml}_{\mathrm{DMEM}}$ of $\mathrm{Fe}_{3} \mathrm{O}_{4}, \mathrm{SiO}_{\mathrm{x}}-$ $\mathrm{Fe}_{3} \mathrm{O}_{4}$ or $\mathrm{AC}-\mathrm{Fe}_{3} \mathrm{O}_{4}$. Percentage of $\mathrm{A} 549^{\mathrm{HSP}}$ cells expressing EGFP after incubation with MNPs and AMF treatment $\left(\mathrm{f}=128 \mathrm{kHz}, \mathrm{H}_{0}=20.3 \mathrm{kA} / \mathrm{m}\right)$. THD is the total heat dose per cell, i.e. the energy released by the MNP per cell due to exposure to the AMF. 


\section{Graphical Table of Contents}

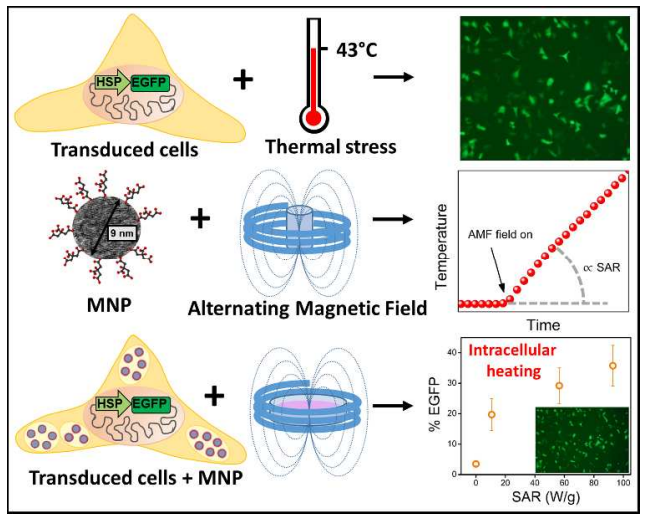

